\title{
„DUCHY OSÓB ŻYJĄCYCH" (IKIRYŌ) JAKO TREŚCI NIEŚWIADOMOŚCI W KAFCE NAD MORZEM MURAKAMIEGO HARUKIEGO
}

\author{
AGNIESZKA KOZYRA \\ (Uniwersytet Warszawski)
}

Słowa kluczowe: Murakami Haruki - psychoanaliza - archetyp Cienia - archetyp Trickstera -
„żywe duchy” ikiryō

Key words: Murakami Haruki - psychoanalysis - archetype of Shadow archetype of Trickster - "living ghosts" ikiryō

\begin{abstract}
Abstrakt: Agnieszka Kozyra. „DUCHY OSÓB ŻYJĄCYCH” (IKIRYŌ) JAKO TREŚCI NIEŚWIADOMOŚCI W KAFCE NAD MORZEM MURAKAMIEGO HARUKIEGO. PORÓWNANIA 18, 2016. T. XVIII. S. 155-172. ISSN 1733-165X. Autorka analizuje motyw ikiryō, czyli ducha osoby żyjącej w powieściKafka nad morzem Murakamiego Harukiego starając się udowodnić, że odpowiada on różnym rodzajom treści nieświadomości zgodnie z psychoanalityczną typologią Gustava Junga. Motyw ikiryō występuje w mitologii i folklorze Japonii, a według Junga, baśnie, legendy czy mity wyrażają ekspresję psychicznych procesów nieświadomości zbiorowej i wraz z ideami religijnymi dostarczają symboli, z pomocą których treść nieświadomości może być skanalizowana do świadomości, a następnie zinterpretowana i zintegrowana. Autorka wykazuje, że ikiryō w powieści Murakamiego jest wieloznacznym pojęciem - stanowi bowiem zarówno archetyp Cienia, jak i wyparte traumatyczne treści nieświadomości indywidualnej. Murakami na przykładzie swojego bohatera, Kafki, ukazuje, że bez integracji tych treści nie jest możliwe funkcjonowanie silnej i odpowiedzialnej osobowości. Ikiryō są także związane z archetypem Cienia jako złem absolutnym, które nie jest abstrakcyjnym pojęciem, ale energią psychiczną związaną ze sferą emocji. Energia ta nie jest pod kontrolą podmiotowej świadomości, ale posiada pewną autonomię. Brak woli człowieka, by przeciwstawić się złu, które jest w nim samym, zostało najpełniej przejawione $\mathrm{w}$ archetypowym obrazie Cienia jako ikiryō, czyli duchu osoby żyjącej, nad którym jej ego nie ma żadnej kontroli.
\end{abstract}

Abstract: Agnieszka Kozyra."LIVING GHOSTS" (IKIRYŌ) AS THE CONTENTS OF SUBCONSCIOUSNESS IN KAFKA ON THE SHORE BY MURAKAMI HARUKI. COMPARISONS 18, 2016. Vol. XVIII. P. 155-172. ISSN 1733-165X. 'Ghosts of a living person' (ikiryō) as the content 
of Subconsciousness in Murakami Haruki's Kafka on the Shore The authoress analyses the image of ikiryō, 'ghost of a living person' in Murakami Haruki's novel titled Kafka on the Shore trying to prove that ikiryō can be regarded as the manifestation of various contents of Subconsciousness according to the psychoanalytic typology presented by Carl Gustav Jung. The image of ikiryō can be found in Japanese mythology and folklore which is in accord with Jung's statement that legends and myths represent expressions of collective Subconsciousness and provide important symbols. Such symbols can be helpful in the process of transferring the contents of the Subconsciousness into the consciousness, so that they could be interpreted and integrated. The authoress shows that ikiryō in Murakami's novel has two main meanings: it is an equivalent of both the archetype of the Shadow and traumatic contents of consciousness, which were driven out to the Subconsciousness. Murakami emphasizes that without integrating such traumatic contents, the personality cannot be strong and stable. Ikiryō is also the Shadow as the absolute evil, which is not an abstract notions but psychic energy related to emotions. Psychic energy cannot be fully controlled by subjective consciousness because it also belongs to the Subconsciousness. The psychological situation of an individual who has no will to resist their own evil inclinations is represented in the archetype of the Shadow as ikiryo - 'the ghost of a living person, who cannot be controlled when it leaves the sleeping body and torments people he hates.

Powieść Murakamiego Harukiego (ur. 1949 r.) pt. Umibe no Kafuka (Kafka nad morzem, 2002) nie poddaje się prawom logiki czy przyczynowości, przeplatana jest surrealistycznymi obrazami w konwencji snu na jawie. Można odnaleźć w niej liczne tropy literackie (np. imię głównego bohatera jako nawiązanie do Procesu Kafki), które tworzą labirynt hermeneutycznych odniesień. Narracja jest prowadzona w typowy dla Murakamiego sugestywny i zaskakujący sposób, z pewnością będący jednym z głównych powodów jego niezwykłej popularności. Moim zdaniem Murakami sam najlepiej określił swój styl, pisząc o piosence jednej z bohaterek swojej powieści: „słowa, jedno po drugim, przenikają do serca, tworząc obrazy przerastające znaczenie; miękko obmywają świadomość czytelnika jak wiosenny deszcz zraszający kamienie"... (Murakami 306).

Główny bohater tej powieści, piętnastoletni Kafka Tamura, ucieka z domu w Tokio na wyspę Shikoku, gdzie znajduje azyl w tajemniczej prywatnej bibliotece pod opieką hermafrodyty pana Ōshimy. Ucieka przed ojcem, który przepowiedział, że jego syn go zabije i dopuści się kazirodztwa ze swoją matką i siostrą. Pewnego dnia Kafka budzi się w zagajniku przy świątyni i nic nie pamięta, a jego ubranie poplamione jest krwią. Wkrótce dowiaduje się, że jego ojciec został zamordowany w Tokio w tym samym dniu, kiedy on stracił przytomność na Shikoku. Kafka podejrzewa, że pani Saeki, pracująca w bibliotece, jest jego matką, która opuściła go zabierając ze sobą adoptowaną córkę, kiedy miał cztery lata. Czytelnik 
zdany jest jedynie na domysły, gdyż do końca nie może być pewny ani tego, że Saeki jest matką Kafki, ani tego, że napotkana w autobusie Sakura jest rzeczywiście jego siostrą. Nie jest także jasne, czy „kazirodcze” sceny w powieści są rzeczywistymi wydarzeniami, czy też stanowią jedynie fantazje bądź sny Kafki.

Drugim równoległym wątkiem fabuły jest podróż na Shikoku pana Nakaty, staruszka, który w dzieciństwie stracił cząstkę swojej duszy i stał się wtórnym analfabetą. Cofnął się psychicznie do stanu dziewięciolatka, otrzymał rentę inwalidzką. Dorabiał sobie, poszukując zaginionych kotów, gdyż potrafi porozumiewać się z tymi zwierzętami. Nie wie, dlaczego musi jechać właśnie na Shikoku, jakby wzywała go jakaś tajemnicza siła. W podróży pomaga Nakacie młody kierowca ciężarówki, Hoshino. Nakata przypomina mu własnego dziadka, który chronił go zawsze, gdy znalazł się w tarapatach w okresie młodzieńczego buntu. To Hoshino ostatecznie pomaga Nakacie znaleźć magiczny „kamień, który otwiera wejście". Mimo realistycznych opisów i nastroju niczym z powieści detektywistycznej $^{1}$, Murakami nie doprowadza żadnego wątku do ostatecznej konkluzji, a czytelnik czuje się zdezorientowany płynnym przejściem fabuły od drobiazgowych opisów kulinarnych preferencji bohaterów do niezwykłych zdarzeń, takich jak spadanie z nieba ryb czy pijawek. Do tego pojawiają się fantastyczne postaci demoniczny Johnny Walker (z etykiety whisky) i tajemniczy, lecz zabawny pułkownik Sanders (wizerunek sieci restauracji „,Kentucky Fried Chicken”).

W tym artykule chciałabym poddać analizie motyw ikiryō, czyli ducha osoby żyjącej w powieści Kafka nad morzem oraz udowodnić, że odpowiada on różnym rodzajom treści nieświadomości zgodnie z psychoanalityczną typologią Gustava Junga2. Motyw ikiryō występuje w mitologii i folklorze Japonii. Według Junga, baśnie, legendy czy mity wyrażają ekspresję psychicznych procesów nieświadomości zbiorowej. Wraz z ideami religijnymi dostarczają symboli, z pomocą których treść nieświadomości może być skanalizowana do świadomości, a następnie zinterpretowana i zintegrowana. Baśnie czy mity osnute są wokół tematów archetypowych ${ }^{3}$, a przekazanie $\mathrm{w}$ ten sposób ich treści miało na celu oswojenie ciemnych sił, które budziły lęk (Samuels, Shorter, Plaut 45).

${ }^{1}$ Na przykład rozbudowany wątek o śledztwie w sprawie utraty przytomności przez grupę dzieci spacerujących w górach w czasie II wojny światowej i podejrzeniach, że było to spowodowane użyciem przez Amerykanów jakiejś nowej broni chemicznej.

${ }^{2} \mathrm{~W}$ polskim przekładzie Umibe no Kafuka termin ten został przetłumaczony jako „żywy duch”, ale nie jest to precyzyjne określenie - duch osoby zmarłej nie jest „martwym duchem”.

${ }^{3}$ Archetyp to wrodzona część psyche stanowiąca strukturyzujące wzorce zachowania powiązane $\mathrm{z}$ instynktem. Jest to hipotetyczna całość niemożliwa do ujęcia w swej istocie, a jedynie oczywista przez swoje przejawianie się, czyli archetypowy obraz. Archetypy odnoszą się do zbiorowej nieświadomości, która zawiera nawarstwienia treści odnoszących się do pierwotnych reakcji na powszechnie ludzkie sytuacje - lęk, niebezpieczeństwo, walka z przemocą, wzajemny stosunek między płciami, rodzicami i dziećmi, postawy wobec nienawiści i miłości, wobec narodzin i śmierci. Zbiorowa nie- 
Będę starała się wykazać, że ikiryō w powieści Murakamiego jest wieloznacznym pojęciem - stanowi bowiem zarówno archetyp Cienia, jak i wyparte treści nieświadomości indywidualnej. Zdaniem Junga duchy są dowodem na realność świata duchowego, świata psyche, innego niż cielesność (Samuels, Shorter, Plaut 54).

\section{Duch Damy Rokujō jako archetypowy obraz Cienia}

Murakami w swojej powieści używa terminu ikiryō, a ponadto wskazuje na jego kontekst kulturowy - przez nawiązanie do najbardziej znanej literackiej postaci ducha osoby żyjącej, czyli ducha damy Rokujō z Genji monogatari (Opowieść o księсіu Genji, XI w.) autorstwa Murasaki Shikibu (?978-?1016) ${ }^{4}$. Rokujō była zazdrosna do szaleństwa o młodszego od niej o siedem lat księcia, który przestał darzyć ją uczuciem. Jej mściwy duch w czasie snu opuszczał jej ciało i dręczył Damę Aoi, żonę Genjiego, która była wtedy w ciąży. Opętanie przez ducha Rokujō spowodowało, że Aoi zachorowała i zmarła. Rokujō, kobieta wytworna i posiadająca wysoką rangę na dworze cesarskim, słynęła ze swoich zdolności poetyckich. Trudno jej było przyznać się nawet przed samą sobą, jak bardzo pożąda księcia kiedy ten chciał ją odwiedzić, zachowywała się odpychająco, pragnąc ukarać go za długi okres braku kontaktu, mimo że niemożność widzenia się z nim sprawiała jej katusze. Gdy usłyszała o chorobie Aoi, wmówiła sobie, że nie czuje do niej niechęci, mimo że została przez nią upokorzona w czasie Święta Malw (jap. Aoi matsuri), ponieważ jej powóz został zepchnięty przez powóz Aoi. Aoi, która była w zaawansowanej ciąży, została nawiedzona przez złego ducha, dziwne ataki zdarzały coraz częściej, powodując ostry ból i duszności. Rokujō przyśniło się, że znajduje się w komnacie Aoi i przepełniona wściekłością wlecze swoją rywalkę po podłodze, maltretując ją. Na jawie nigdy nie zachowywała się w tak gwałtowny sposób, dlatego miała wrażenie, że śni o innej osobie. Niepokoiło ją tylko to, że pogłoski o tym, iż to jej duch nawiedza Aoi mogą popsuć jej reputację na dworze. Książę Genji dowiedział się prawdy, kiedy zwijająca się z bólu Aoi przemówiła do niego głosem Rokujō - nie mógł pomylić jej wyszukanego i poetyckiego stylu wyrażania się z nikim innym. Aoi urodziła syna Genjiego, ale wkrótce potem Rokujō doprowadziła ją do śmierci (Murasaki 34-41).

W sztuce teatru nō Aoi no ue (Pani Aoi) Rokujō tak wyraża swoją nienawiść do rywalki:

świadomość jest duchowym dziedzictwem rozwoju ludzkości, odrodzonym w każdej strukturze indywidualnej psyche.

${ }^{4}$ Fragmenty tej powieści przetłumaczone zostały na język polski w: Dziesięć wieków Genji monogatari w kulturze Japonii. Red. Iwona Kordzińska-Nawrocka. Warszawa, 2009. 


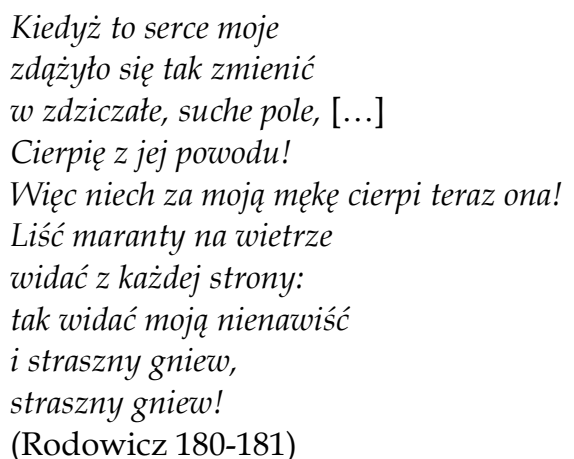

Warto zauważyć, że nawiązanie do tego klasycznego wątku pojawia się także w wersji współczesnej w sztuce Mishimy Yukio (1925-1970) pt. Aoi no ue (Pani Aoi). Jej bohater, Hikaru Wakabayashi, kiedyś związał się ze starszą od siebie majętną i elegancką kobietą, Yasuko Rokujō. Hikaru porzucił ją, a potem ożenił się z Aoi. Akcja sztuki rozpoczyna się w szpitalu, gdzie przebywa Aoi. Hikaru, który przyszedł ją odwiedzić, dowiaduje się od pielęgniarki, że jego żona miewa koszmarne sny i krzyczy w nocy. Pielęgniarka opowiada mu także, że co noc przychodzi jakaś dziwna kobieta. Pojawia się wkrótce potem, jest to duch Yasuko Rokujō. Układa u wezgłowia chorej „niewidzialne kwiaty bólu”, ich pąki rozwijają się w kwiaty barwy popiołu. Wydają cuchnący odór, a spod ich liści wyrasta mnóstwo straszliwych cierni. Kwiaty sprawiają, że Aoi widzi we śnie swoją twarz starą, pokrytą zmarszczkami. Kiedy duch dotyka lekko gardła Aoi, chora dusi się, krew napływa jej do twarzy. Duch Rokujō wyznaje Hikaru miłość, przypomina mu razem spędzone upojne chwile. Hikaru rani ją jeszcze bardziej mówiąc, że wcale nie był tak bardzo w niej zakochany, że czuł się z nią, jakby był w złotej klatce. W końcu Hikaru domyśla się, iż ma do czynienia z duchem i próbuje się dodzwonić do Yasuko do domu. Jego telefon budzi Yasuko, nie zdającą sobie sprawy z tego, co się działo podczas jej snu. Jest jednak już za późno, gdyż Aoi nie żyje (Mishima 171-190).

W Kafce nad morzem na pytanie głównego bohatera, czy można zostać za życia duchem, Ōshima odpowiada, że w literaturze Japonii pojawiają się duchy żyjących i za przykład podaje właśnie Opowieść o księciu Genji. Dusze opuszczają nie tylko ciała zmarłych, żywi też, przy wystarczająco silnej woli, potrafią dokonać tego samego - taki sposób myślenia ma korzenie w starożytności i był naturalny dla pierwotnych ludów Japonii (Murakami 92). Ōshima wyjaśnia:

W okresie Heian [794-1185/1192], a przynajmniej w świecie emocjonalnym tego okresu, w niektórych przypadkach można było zostać za życia duchem, przemieszczać się w przestrzeni i realizować swoje zamierzenia. [...] Najciekawsze w opowieści jest to, że Rokujō wcale nie zorientowała się, że czasami zmienia się w ducha. [...] Sama o tym nie wiedząc, przesuwała się przestrzeni, przechodziła tunelem podświadomości i docierała do sypialni pani Aoi. Jest to jedna z najbardziej przejmujących, mrożących krew 
w żyłach scen z Opowieści o księciu Genji. Później dowiaduje się, co nieświadomie uczyniła, obawia się kary za grzechy, goli głowę i idzie do klasztoru. (Murakami 302)

Murakami wyraźnie łączy archetyp Cienia z motywem ikiryō w Opowieści o księciu Genji, gdyż pisze:

Świat dziwów to inaczej ciemność naszych serc. Zanim w dziewiętnastym wieku pojawili się Freud oraz Jung i rzucili światło psychoanalizy na naszą podświadomość, korelacja między tymi dwiema ciemnościami - ciemnością prawdziwą i ciemnością serca - była dla ludzi oczywista, nie wymagała zastanawiania, nie była nawet metaforą" (Murakami 302). Zdaniem Murakamiego świat baśni i mitów odzwierciedlał oczywiste dla wszystkich stany emocjonalne człowieka. Mimo rozwoju cywilizacji ciemność serca człowieka pozostała niezmieniona. „To, co nazywamy ego albo świadomością, jest $\mathrm{w}$ większości zatopione w strefie ciemności jak góra lodowa. Ta separacja w pewnych przypadkach wywołuje poczucie głębokiej sprzeczności i popłoch. (Murakami 303)

\section{Archetyp Cienia w powieści Kafka nad morzem}

W 1945 roku Jung podał najbardziej jasną i lapidarną definicję archetypu Cienia jako tego, czym człowiek nie chce być (Samuels, Shorter, Plaut 47). Archetyp Cienia to, według tego filozofa, negatywna strona osobowości, suma wszystkich cech pozbawionej wartości oraz prymitywnej strony natury ludzkiej. Każdy człowiek ma w sobie własną ciemną stronę, którą traktuje jako coś obcego, jakby istniała $\mathrm{w}$ nim jakaś inna osoba. Jung zdawał sobie jasno sprawę $\mathrm{z}$ realności zła w życiu człowieka. Wszystko, co substancjonalne ma swój cien, dlatego użył tej metafory, aby wyrazić to, że ego ma także swój cień, czyli swoje przeciwieństwo. Takim samym przeciwieństwem jest światło i mrok. Każdy człowiek ma swój cien, jeśli zostanie wyparty i odizolowany od świadomości, nigdy nie uda się go kontrolować czy zmienić, może się wtedy pojawić zupełnie nieoczekiwanie, kiedy słabnie oddziaływanie ego ${ }^{5}$. Cień tworzy wtedy nieświadomą przeszkodę, udaremniając człowiekowi jego nawet najbardziej szczere intencje, na przykład intencję, żeby nie ranić drugiej osoby ${ }^{6}$. Symbolika ikiryō wskazuje właśnie na te negatywne treści

${ }^{5}$ Jung zdecydowanie odróżnia swoją definicję ego od teorii Freuda. Według Junga, ego to centrum świadomości, które ma swoje ograniczenia i niekompletność w stosunku do całej osobowości. Domeną ego jest poczucie indywidualnej tożsamości, stałość osobowości, poczucie ciągłości w czasie, pośrednictwo między świadomością i nieświadomością, rozpoznawanie i testowanie rzeczywistości. Jednak jest ono podporządkowane jaźni w tym sensie, że to jaźń (i zawarta w niej sfera nieświadomości) jest siłą determinującą. Początkowo ego jest zanurzone w jaźni, lecz następnie różnicuje się w niej.

${ }^{6}$ Jung przypisywał Freudowi zasługę zwrócenia uwagi współczesnego człowieka na rozdarcie między jasnymi i ciemnymi stronami psychiki ludzkiej. 
psychiczne, które nie są kontrolowane przez świadomość, tak jakby sprawcą był ktoś inny, jakby rzeczywiście jakaś cząstka duszy człowieka mogła funkcjonować niezależnie od jego ego.

Kiedy Cień dostaje się do świadomości, poczucie braku kontroli ze strony ego jest przerażające. Kafka wspomina, że czasami ma napady wściekłości i wtedy czuje się tak, jakby ktoś nacisnął przycisk w jego głowie i ciało zaczynało działać, zanim mózg pomyśli, miał wtedy wrażenie, jakby jego świadome ego było i jednocześnie nie było obecne (Murakami 118). Tego rodzaju doświadczenie braku kontroli nad sobą Kafka kojarzy ze swoją uratą przytomności w zagajniku przy świątyni, sugerując, że musiał się przemieszczać i robić różne rzeczy zupełnie nie będąc tego świadomy (Murakami 118). Pamiętał, że jadł obiad w przydworcowej restauracji, a tego, co działo się potem, nie może sobie przypomnieć. Kiedy odzyskał przytomność, z przerażeniem zauważył, że jego koszulka została poplamiona krwią, chociaż sam nie jest ranny. Można by dojść do wniosku, że oddzielenie się duszy od ciała nie powinno mieć wpływu na stan ciała, które pozostaje nieruchome w jakimś miejscu. Jednak cielesne ślady działalności ikiryō występują także w Opowieści o księciu Genji. Dama Rokujō nie zdawała sobie sprawy, że w czasie snu jej duch opuszcza ciało, ale czuła, że dzieje się coś dziwnego - po przebudzeniu czuła, że jej szaty są przesiąknięte zapachem palonego kadzidła, który był częścią egzorcyzmów odprawianych przez mnichów, starających się uleczyć Damę Aoi. Tego typu "ślady cielesne" aktywności ducha" mieszczą się w teorii Junga, gdyż wyróżniał "ciało subtelne" jako "fizyczną materializację psychiki” (Samuels, Shorter, Plaut 47).

$\mathrm{Za}$ archetypowy obraz czy też projekcję Cienia jako zła absolutnego w Kafce nad morzem można uznać groteskową postać Johnniego Walkera, zajmującego się łapaniem i zabijaniem w okrutny sposób kotów. Zjada serca zabitych kotów, a $\mathrm{z}$ ich dusz wyrabia specjalne flety, których dźwięku zwykli ludzie nie mogą usłyszeć. Flet z kociej duszy daje mu szczególną moc, gdyż nikt nie może się do niego zbliżyć, kiedy na nim zagra. Dźwięk fletu sprawia, że może zdobyć ,jeszcze większe dusze", aż w końcu wykona "flet na miarę wszechświata" (Murakami 190). Johnnie Walker twierdzi, że całe życie zbiera dusze i jest tym zmęczony. Chce, by Nakata zamordował go, powodowany strachem i nienawiścią, właśnie dlatego na jego oczach zabija koty, patroszy je, a potem zjada ich serca. Johnnie Walker zdaje sobie sprawę, że Nakata nie potrafi nikogo zabić, dlatego nawiązuje do sytuacji, w której wysłany na front młody człowiek niemający morderczych skłonności, nagle musi zabijać, gdyż inaczej sam zostanie zabity. „Trik w zabijaniu ludzi polega na tym, żeby się nie wahać. Wykonać szybko, myśląc o swoich wielkich uprzedzeniach" (Murakami 194). Stawia Nakatę przed dylematem: czy pozwoli mu zabijać koty, czy też go zabije, gdyż tylko tak może go powstrzymać. Dla rozumiejącego mowę kotów Nakaty zwierzęta te są jak najbliżsi przyjaciele, dlatego staje przed dylematem miłośnika pokoju powołanego do wojska i wysłanego 
do walki - czy będzie zabijać, czy też będzie się biernie przyglądać jak wrogowie zabijają jego towarzyszy.

Niewątpliwie dla Murakamiego złem absolutnym jest krzywdzenie innych postrzegane jako uzasadniona racjonalnie misja, obowiązek, który nie budzi wyrzutów sumienia, a co najwyżej znużenie. Johnnie Walker powtarzając "misja to misja" bez wahania rozcina brzuch sparaliżowanym, lecz świadomym kotom i z apetytem zjada wykrojone im serca. Takie poczucie obowiązku i misji w kontekście zła łączy się z rozważaniami Kafki na temat lektury książki o procesie Adolfa Eichmanna (1906-1962). Gdy Eichmann otrzymał rozkaz „rozwiązania kwestii żydowskiej" przystąpił do tego metodycznie i praktycznie. Nie miał żadnych wątpliwości i rozterek, zajęły go wyłącznie obliczenia i kalkulacje, jak pozbyć się z Europy jedenastu milionów ludzi.

Ile będzie potrzebnych pociągów towarowych i ilu Żydów da się upchnąć w jednym wagonie? Ile procent umrze śmiercią „naturalną" podczas transportu? Co zrobić, żeby zrealizować ten plan przy użyciu mniejszej liczby osób? Jaki będzie najtańszy sposób pozbycia się ciał: czy je spalić, pogrzebać, stopić? (Murakami 194)

Na procesie Eichmann, którego plan doprowadził do śmierci połowę zaplanowanej liczby Żydów, nie ma wyrzutów sumienia i nie rozumie, dlaczego wytoczono mu proces. Był przecież tylko skutecznym i obowiązkowym wykonawcą zadania, które mu przydzielono.

Nad złem, które niesie wojna i walka zastanawia się także Kafka: „Dlaczego ludzie walczą? Dlaczego setki tysięcy, miliony ludzi muszą łączyć się w grupy i nawzajem zabijać?" (Murakami 177).

\section{„Odpowiedzialność rodzi się w snach"}

W powieści Murakamiego wielokrotnie wspomniane jest, że Nakata rzucał cień „dwa razy jaśniejszy niż inni ludzie” (Murakami 72) W dzieciństwie jego dusza oddzieliła się od ciała, ale wróciła tylko część - przepadła gdzieś połowa jego cienia. To właśnie sprawiło, że osobowość Nakaty jest ułomna i niepełna. Nakata spotyka Johnniego Walkera szukając zagubionej kotki Gomy na prośbę jej właścicielki, gdyż była pupilką jej dzieci. Nakata nie uznaje zabijania i zdaje się nie być do tego zdolny. Widząc, że Johnnie Walker, który na jego oczach okrutnie zamordował już kilka kotów, zamierza zabić kotkę Gomę, nagle wstaje i wbija mu nóż w serce, przy czym „nawet on sam nie mógł tego powstrzymać” (Murakami 201). Nakata wyjaśnia potem, że brak połowy Cienia sprawia, że można porównać jego psychikę do pustego domu, niezamkniętego na klucz. „Każdy, każde stworzenie mogą sobie tam wejść, jak im przyjdzie ochota". Nakata wyznaje, że Johnnie Walker wszedł do jego wnętrza i zmusił go do zrobienia czegoś, czego on sam nie 
chciał zrobić. Nakata czuje się bezwolnym medium, jednak nie może się przeciwstawić, gdyż „nie ma nic w środku”. Walker zmusił go do „przelania krwi, która nie powinna być rozlana" (Murakami 413). Poźniej Nakata twierdzi, że na polecenie Johnniego Walkera „zabił go w imieniu piętnastoletniego syna, który powinien tam być" (Murakami 520).

Pojawiają się następujące wątpliwości: Czy to Cień (zło absolutne, symbolizowane przez Johnniego Walkera) sprawił, że Nakata popełnił morderstwo? Czy też duch Kafki (Cień Kafki) opuścił jego ciało i wstąpił w Nakatę a potem zabił Johnniego Walkera, czyli swojego ojca? Czy dlatego Kafka widział krew na swoim ubraniu, kiedy się ocknął na Shikoku, a Nakata po zabiciu Johnniego Walkera w Tokio nie był poplamiony krwią?

Powyższe pytania w powieści pozostają bez jasnej odpowiedzi. Najważniejszą konkluzją wydają się być słowa Kafki, który uważa, że nie jest ważne, jak zginął jego ojciec. Skoro nienawidził ojca i pragnął jego śmierci, musi wziąć odpowiedzialność za swoje sny, za swoją wyobraźnię, za swoją nienawiść (Murakami 179)7 Jest to odpowiedzialność nie za czyny, ale za intencje, jednak właśnie intencje są źródłem zła.

Moim zdaniem Johnnie Walker może być łączony z postacią ojca Kafki tylko w szerszym kontekście definicji archetypu Cienia. Ojciec Kafki uległ swojemu Cieniowi, gdyż odtrącił i nienawidził swojego syna. Nie pasuje do niego wizerunek mordercy kotów, sadysty obcinającego im głowy i zjadającym ich serca, aby wypełnić powierzoną mu misję $\mathrm{z}$ poczucia obowiązku bez wyrzutów sumienia. Ojciec Kafki, znany rzeźbiarz, po odejściu żony z adoptowaną córką, zamyka się w sobie. Nienawidząc syna, przepowiada mu, że popełni ojcobójstwo i kazirodztwo z własną matką i siostrą. Kochał kobietę, która nie tylko od niego odeszła, ale nigdy go tak naprawdę nie kochała, nigdy jej nie zdobył. Dlatego chciał umrzeć z ręki jej syna, który ciągle mu ją przypominał, i rzucił na niego klątwę grzechu kazirodztwa, aby „odziedziczył wolę posiadania tej samej kobiety, co ojciec” (Murakami 391-392).

Główny problem, z jakim zmaga się Kafka, to nie zło absolutne, które uosabia Johnnie Walker, ale odrzucenie przez rodziców. Rozpaczliwie zadaje sobie pytanie: „Czyżbym nie miał prawa być kochany przez własną matkę?" (Murakami 530). To, co musi zrobić Kafka, by wyzwolić się z "klątwy”, to zrozumieć strach i gniew najbliższych mu osób, które go odtrąciły. Musi im wybaczyć, gdyż tylko wtedy uwolni się od swojej obsesji i nie będzie powtarzać ich błędów (Murakami 533).

Kafka uciekł z domu nie tylko z powodu nienawiści do ojca - gdyby został, byłby „bezpowrotnie stracony”, czyli „zmieniłby się w kogoś, kim nie powinien

${ }^{7}$ Murakami cytuje fragment wiersza Williama Butlera Yeatsa: "In dreams begin the responsibilities". 
być" (Murakami 334). Najbardziej samotny nastolatek, jakim jest Kafka, musi zmierzyć się również z kompleksem Edypa, czyli ze swoją ciemną sferą popędów. Tak jak Edyp ucieka przed przeznaczeniem tylko po to, by uświadomić sobie, że zło jest w nim. Musi nauczyć się kontrolować swój Cień. Chociaż można by uznać, że Cień należy po prostu wyeliminować, Jung podkreślał, że właśnie Cień w pewnym sensie nas uczłowiecza. Nie można usunąć Cienia, można „nawiązać z nim kontakt” w procesie konfrontacji i dzięki temu można „przełamać jego przymusowy uścisk", czyli nie dopuścić, żeby Cień zaczął całkowicie kontrolować świadomość. Nie chodzi o to, żeby utożsamić się z Cieniem, należy zacząć uświadamiać sobie sytuacje i obrazy, które najprawdopodobniej mogą wywołać projekcje Cienia. „Proste stłumienie Cienia jest lekarstwem równie mało skutecznym, jak zgilotynowanie jako środek na ból głowy" (Jacobi 155). Tylko uświadomiony Cień może być do pewnego stopnia kontrolowany, podczas gdy nieuświadomiony Cień od razu jest w stanie zawładnąć świadomością. Kafka zdaje sobie także sprawę $\mathrm{z}$ tego, że konfrontacja ze swoimi demonami wymaga silnego ego, które nie pozwoli na dominację treści nieświadomości.

Z punktu widzenia psychoanalizy Junga fantazje kazirodcze stanowią skomplikowaną metaforę w procesie rozwoju psychologicznego dziecka. Kryje się w nich tęsknota za bliskością, a konfrontacja z nimi wiąże się z koniecznością wytworzenia psychologicznych barier, które pomogą nie ulegać ślepym popędom. Jednak najpierw należy skonfrontować się z nieświadomymi popędami, aby móc je kontrolować. Właśnie dlatego Kafka mówi do siebie: „Nie chcesz być więcej na łasce różnych rzeczy. Nie chcesz, żeby mieszały ci w głowie. Zabiłeś już ojca. Zgwałciłeś matkę. A teraz wszedłeś w siostrę. Jeżeli jest jakaś klątwa, chętnie ją przyjmiesz. Zamierzasz wykonać cały program. Chcesz jak najszybciej zrzucić $\mathrm{z}$ barków ten ciężar. Żyć w pełni jako ty, a nie uwikłany w knowania kogoś innego" (Murakami 494).

Kafka przeczuwa, że jedyny sposób na kontrolę Cienia, to konfrontacja z nim, chociaż niezwykle trudno zaakceptować mu tę całą ciemność jako należącą do niego. Zazwyczaj człowiek uważa, że przyznanie się do swojej "ciemnej strony” musi oznaczać zniszczenie jego pozytywnego wizerunku i osłabienie ego. Jednak tylko ten, kto jest w stanie skonfrontować się ze swoim Cieniem, bierze za niego odpowiedzialność. Nie może już zwalać winy na innych, na okoliczności, nie może już godzić się na to, że będą działać w nim siły nieświadomości, nad którymi świadomość nie ma kontroli. Jest w stanie wystawić się na impulsy nieświadomości nie utożsamiając się z nimi ani od nich nie uciekając (Jacobi 173). Kiedy wyparte treści w nieświadomość stają się mniej lub bardziej jasną ideą, wtedy tracą swoją zdolność owładnięcia świadomości - stają się niejako oswojone. Nadal sprawiają ból, ale nie są w stanie zdominować świadomości.

Jung podkreślał, że podstawowych problemów życia nie da się rozwiązać $\mathrm{z}$ nich się po prostu wyrasta (Casemont 97). Dlatego Kafka, nie wypierając swojego 
Cienia, ale mierząc się z nim, sprawił, że traumy z dzieciństwa przestały mieć wpływ na jego życie. Nie oznacza to wyzwolenia od nich na zawsze, gdyż Cień zawsze będzie się czaił w nieświadomości. Kafka, tak jak każdy inny człowiek, ma „wypaloną w duszy klątwę", którą jest „niezmienny ciemny chaos”. Strach, gniew i niepokój zawsze uparcie torturują jego serce (Murakami 516). Nie można pozbyć się Cienia, można tylko wypracować procedury konfrontacji z nim. Kafka zwyciężył, gdyż „wpuścił do swojego wnętrza jasne światło, rozmroził zamarznięte części swojego serca i dlatego odzyskał siebie, a jednocześnie stał się naprawdę silnym człowiekiem (Murakami 517).

\section{Pozytywne wizerunki ikiryō w literaturze Japonii}

Kafka zadaje pytanie o to, czy wszystkie duchy żyjących powstały z negatywnych pobudek. Ōshima, zastrzegając się, że jego wiedza jest ograniczona, twierdzi, iż nie ma przypadków ludzi, którzy stali się duchami za życia, chcąc doprowadzić do pokoju na świecie albo zrealizować jakiś logiczny cel. Kafka zastanawia się nad tym, czy można za życia zostać duchem z miłości. Ōshima odpowiada, że skoro duchy zmarłych mogą powracać z miłości, o czym mówi opowiadanie Uedy Akinariego (1734-1809) ze zbioru Ugetsu monogatari (Po deszczu przy księżycu, 1968-76) pt. Kikka no Yaku (Powrócę w Dniu Chryzantem), może jest to także możliwe w przypadku duchów osób żyjących (Murakami 304).

Według rodzimych wierzeń Japonii, sintoizmu (shintō, dosł. droga bogów), bogowie mają cztery dusze: duszę łagodną (jap. nigimitama), duszę gniewną (jap. aramitama), duszę łaskawą (jap. sakimitama) i duszę cudowną (jap. kushimitama). Według mitologii, Japończycy są potomkami bogów ziemskich, a jedynie cesarz i niektórzy arystokraci wywodzą się od bogów niebiańskich - można więc uznać, że w mitologii Japonii podział na cztery dusze dotyczy także ludzi. Warto zwrócić uwagę na to, że dla Junga teorie istnienia więcej niż jednej duszy człowieka w różnych kulturach są wyrazem intuicyjnego przeświadczenia, że psychika nie jest jednorodna, ale kryje w sobie pluralizm, różnorodność i do końca jest niepoznawalna (Samuels, Shorter, Plaut 55). W Kronikach japońskich (Nihongi, 720) opisana jest scena, w której bóg Ōkuninushi ${ }^{8}$ użala się, że został sam, bez żadnych pomocników, a wtedy pojawia się nad morzem świetlista kula. Okazało się, że była to jego dusza cudowna odpowiedzialna za kreatywność, która przypomniała mu, jak wielką moc sam posiada, a więc da sobie radę bez wsparcia innych. Ōkuninushi

\footnotetext{
8 Według mitologii Ōkuninushi był potomkiem boga wiatru i burzy, Susanoo, który zszedł na ziemię. Ōkuninushi poślubił córkę Susanoo, Suseribime, i przejął po nim władzę na archipelagu japońskim. Sprawował tę władzę godnie, a potem zrzekł się jej na rzecz potomka bogini słońca, Amaterasu.
} 
nie tylko rozmawiał ze swoją duszą oddzieloną od niego, ale sprawił, by zgodnie z jej wolą mogła ona osiąść na górze Mimoro (Nihongi 61). Jeśli założymy, że ludzie także mają cztery dusze, tylko o zdolnościach dużo pośledniejszych niż dusze bogów, można by uznać, że nie tylko "gniewna dusza" może się oddzielać od ciała jako mściwe ikiryō, ale także jako „dusza łagodna”.

Przykładem na to, że negatywne emocje nie muszą być przyczyną opuszczenia ciała przez duszę jest opowiadanie Uedy Akinariego pt. Muō no rigyo (Karp wyczarowany ze snu) także ze zbioru Ugetsu monogatari. Malarz Kōgi przez wiele lat $\mathrm{z}$ upodobaniem malował igrające $\mathrm{w}$ wodzie ryby i doszedł $\mathrm{w}$ tym do doskonałości. Często śniło mu się, że sam jest karpiem śmigającym w wodnej toni, a swoje sny także uwieczniał na obrazach. Pewnego dnia ciężko zachorował. Uczniowie znaleźli go leżącego z zamkniętymi oczami i nie oddychającego, jednak jego ciało było ciągle ciepłe, więc nie pochowali go, mając nadzieję, że dusza wróci do ciała. Kōgi ocknął się dopiero po trzech dniach i opowiedział im, że jego dusza wcieliła się w karpia, mógł pływać swobodnie w głębinach, tak jak o tym marzył. Przebudził się w chwili, gdy złowił go rybak i chciał zabić (Ueda 96-104). Chociaż sam Kōgi mówił o sobie jako o zmarłym, fakt, że jego ciało było przez trzy dni ciepłe świadczy o tym, że wcielił się w karpia, będąc ikiryō, czyli duchem żywej osoby9

W powieści Murakamiego Kafka nad morzem Nakata posiada zdolność odrywania swojej duszy od ciała, chociaż nim także nie kierują negatywne emocje. Do końca pozostaje zagadką, co w rzeczywistości było tego przyczyną. Na szkolnej wycieczce do lasu Nakata wraz z innymi dziećmi stracił przytomność - wszyscy leżeli bezwładnie jak „puste pancerze owadów” (Murakami 27). Ich oczy nie były zamknięte, zdawało się, że na coś patrzą, gdyż poruszały się z lewa do prawa, jakby oglądały jakiś krajobraz. Jednak nie reagowały na bodźce $\mathrm{z}$ otoczenia. Wszystko wskazywało na to, że w stanie "oddzielenia duszy" ciała ich obniżyły funkcje do poziomu koniecznego do przetrwania (Murakami 92). Wszystkie dzieci poza Nakatą stosunkowo szybko przebudziły się i nie pamiętały, co się stało. Zdarzenie to nie miało wpływu na ich życie. Jedynie Nakata pozostawał nieprzytomny przez wiele dni, a kiedy obudził się, okazało się, że ma całkowitą amnezję, a do tego stracił zdolność uczenia się czegokolwiek. Jakaś cząstka jego duszy nie wróciła do niego, wszystko wskazuje na to, że był pozbawiony części „duszy gniewnej”, którą można utożsamić z archetypem Cienia. Potrafił za to unosić się nad granicą świadomości „jak motyl” i robił to codziennie. Po drugiej stronie granicy świadomości znajdowała się przepaść. „Czasami odrywał się od krawędzi i krążył nad przepaścią, od widoku której kręciło mu się w głowie. Lecz nie bał się tamtej ciemności ani głębi" (Murakami 116). Nie bał się, gdyż stała się ona jego częścią. Wkraczając

\footnotetext{
${ }^{9} \mathrm{~W}$ starożytnej Japonii był zwyczaj mogari, czyli czuwania przez określony czas przy zwłokach z nadzieją, że dusza wróci do ciała. W przypadku możnowładców grzebanych w kurchanach (kofun) czuwanie miało miejsce w podziemnej komorze grobowej.
} 
do nieświadomości zbiorowej, miała poczucie jedności wszystkiego, niejako roztapiał się w większej całości. „Ponieważ miejsce to nie miało części, nie trzeba było nic tam zmieniać. Niczego dodawać ani ujmować. Nie trzeba myśleć o trudnych rzeczach, wystarczy pozwolić ciału przeniknąć wszystkim" (Murakami 116).

W literaturze Japonii bohaterką, która została ikiryō z miłości jest na przykład cesarzowa Teishi (976-1001) z Namamiko monogatari (Opowieści o Namamiko, 1965)10 autorstwa Enchi Fumiko (1905-1986), nawiązującej do postaci i wydarzeń historycznych. Teishi, mając szesnaście lat, została żoną jednenastoletniego cesarza Ichijō (980-1011; panował: 986-1011). Jej ojciec Fujiwara Michitaka (953-995) był regentem przy małoletnim władcy. Gdyby zatem jego córka urodziła cesarzowi syna, byłby dziadkiem następcy tronu. Właśnie z tego powodu kobiety na dworze cesarskim w okresie Heian stanowiły ważną kartę przetargową w rozgrywkach politycznych. Piękna Teishi była uosobieniem wszelkich cnót i wrażliwości artystycznej. Początkowo traktowała swojego męża jak brata, jednak wraz z upływem czasu zrodziła się między nimi miłość. Teishi po śmierci Michitaki utraciła wpływy na dworze, gdyż jej stryj, Fujiwara Michinaga (966-1028), chciał, by główną małżonką cesarza została jego córka, Shōshi. Udało mu się uzyskać stanowisko regenta, o które starał się brat Teishi, gdyż zdobył poparcie matki cesarza Ichijō, Senshi. Senshi była zazdrosna o miłość, jaką jej syn darzył Teishi. Żeby pozbyć się rywalki swojej córki, Michinaga uknuł intrygę. Przekonał Ayame no miya, jedną z dam dworu, aby udawała, że wpadła w trans na skutek opętania przez ducha Teishi. Jej ustami miała Teishi wyznać, jak bardzo nienawidzi swojej teściowej. Ayame bardzo długo przygotowywała się do tej roli, naśladując sposób poruszania się i wysławiania Teishi (Enchi 76). Jednak cesarz Ichijō, chociaż widział scenę domniemanego opętania Ayame przez ducha żony, nie uwierzył w to i uznał to za spisek Michinagi.

Kiedy Teishi zaszła w ciążę, Michinaga obawiał się, że urodzi syna, następcę tronu, więc postanowił pozbyć się jej ostatecznie. Skazał na banicję braci Teishi, oskarżając ich o rzucanie klątw i uroków, a cesarz Ichijō, mimo że widział, jak bardzo cierpi jego żona, nie mógł temu zapobiec (Enchi 102). Wkrótce w podejrzanych okolicznościach wybuchł pożar w pałacu, a Teishi uratowała się tylko dlatego, że wyniósł ją jeden z oficerów straży, zakochany w niej Tachibana no Yukikuni. Dwórka Teishi, Kureha, która kochała Yukikuniego, z zazdrości zgodziła się pomóc Michinadze ostatecznie skompromitować swoją panią (Enchi 114). Kiedy zachorowała Shōshi, córka Michinagi, rozpuszczono plotki, że nawiedza ją mściwy duch cesarzowej Teishi. Wkrótce potem Kureha odegrała rolę medium opanowanego przez ducha swojej pani w obecności cesarza Ichijō (Enchi 160). Cesarz prawie uwierzył, że ma przed sobą ducha Teishi, który rzucił klątwę na Shōshi, gdy Kureha podeszła do niego i przytuliła się do jego rąk - tak zachowywała się Teishi tylko wtedy, gdy byli sam na sam. Cesarz nie wiedział, że Kureha kiedyś przypadkiem zobaczyła tę scenę.

\footnotetext{
${ }^{10}$ Namamiko oznacza dosłownie „dziecko bóstwa w ciele człowieka” i oznacza szamankę.
} 
W tym momencie w ciało Kurehy naprawdę wszedł duch Teishi, co cesarz odczuł jako jej namacalną obecność. Duch Teishi powiedział: „Proszę wysłuchaj mnie. [...] Nie jest prawdą to, co ci mówiono, wszystkie te złe siły nie mają ze mną nic wspólnego. Dopiero teraz mój duch przybył do ciebie za życia, ten jeden raz, nigdy się już to więcej nie powtórzy" (Enchi 167). Teishi przekonała męża, że nigdy nikogo nie przeklęła i nie zamierza skrzywdzić ani jego matki, ani Shōshi. To w imię ratowania ich miłości Teishi wysłała do ukochanego męża swojego ducha. Wkrótce zmarła na skutek choroby zaraz po urodzeniu córeczki. Jednak przed śmiercią nie pozwoliła, by Michinaga zniszczył piękne uczucie, łączące ją z mężem ${ }^{11}$. Jej postać to duch żyjącej osoby, który pojawia się z czystej miłości.

Z miłości pojawia się także duch Saeki, którego Kafka widzi w bibliotece, ale jest to zupełnie inny wizerunek ikiryō, niż w Namamiko. Nie jest to duch teraźniejszej Saeki, pięćdziesięcioletniej, ale duch pod jej postacią w wieku piętnastu lat, kiedy była szczęśliwa, beztroska i z wzajemnością zakochana. Szczęście nie trwało długo, gdyż ukochany Saeki został zabity w czasie rozruchów studenckich. Okupujący budynek studenci wzięli go omyłkowo za lidera przeciwnej frakcji i podejrzewali go o szpiegostwo. W trakcie przesłuchania przywiązali go do krzesła i bili metalową rurą. Na skutek obrażeń zmarł: miał wgniecioną czaszkę, połamane żebra i zmiażdżone płuca. Jego zwłoki wyrzucono na ulicę (Murakami 215). Warto zauważyć, że studenci ci również przejawiają absolutne zło w rozumieniu Murakamiego, gdyż nie mają żadnych wyrzutów sumienia, a kieruje nimi poczucie misji. To, co najbardziej w nich przerażające to: „wąskie horyzonty, brak wyobraźni, nietolerancja; oderwane od rzeczywistości tezy, pusta terminologia, uzurpowane ideały, sztywne systemy" (Murakami 215).

Saeki nigdy nie pogodziła się ze śmiercią ukochanego. Pamięć szczęśliwych chwil nad morzem $w$ rodzinnym mieście stała się enklawą $w$ jej nieświadomości to tutaj skrywała się niezdolna do normalnego życia. Kafka widzi jej ducha, jak przychodzi, co noc, do pokoju, w którym nocował jej ukochany. Dziewczyna $\mathrm{w}$ niebieskiej sukience siadała przy biurku przed obrazem, przedstawiającym ich dwoje szczęśliwych na plaży i pogrążona $\mathrm{w}$ przyjemnych wspomnieniach uśmiechała się lekko od czasu do czasu (Murakami 292).

Ducha piętnastoletniej Saeki można uznać za kompleks rozumiany jako „oderwaną duchową część osobowości" (Jacobi 56). Jung podkreślał, że kompleks nie musi oznaczać poczucia mniejszej wartości jednostki. Wszyscy mają kompleksy, są one niezbędne do prawidłowego funkcjonowania psychiki, o ile nie staną nie "chorymi kompleksami", a więc wtedy, gdy całkowicie zdominują świadomość. Źródłem kompleksu jest trauma, wstrząs emocjonalny, wskutek czego część psyche zostaje zasklepiona lub odłączona (Jacobi 59). Kompleks działa w obszarze

${ }^{11}$ Kureha została najpierw oskarżona o udawanie medium przez Michinagę, który uznał, że go zdradziła, a potem popełniła samobójstwo w pobliżu grobu Teishi. 
świadomości jako ciało obce. Duch Saeki jako odłączony fragment jej psyche nie mści się na nikim, ale jest zagrożeniem dla jej własnej osobowości.

Saeki jest przykładem osoby, której traumatyczne przeżycia sprawiły, że potrafi żyć tylko przeszłością, większa cząstka jej duszy zatrzymała się bowiem w azylu nieświadomości. Saeki przeklęła i znienawidziła wszystko, co było na zewnątrz, szła przez życie nic nie czując. Chciała odzyskać utracone szczęście i dostać się do jakiegoś miejsca, gdzie czas stoi w miejscu (Murakami 334). Użyła „kamienia otwierającego wejście”, co symbolizuje naruszenie równowagi między świadomością i nieświadomością. Błądziła w labiryncie czasu i nie miała ochoty stamtąd wyjść, dlatego właśnie nie potrafiła w pełni i odpowiedzialnie żyć. Po śmierci ukochanego utraciła sens życia, aby je czymś wypełnić, robiła to, co w końcu sprawiało, że raniła siebie i innych. Potem mogła już tylko pogardzać sobą.

Gdyby założyć, że Saeki jest matką Kafki, jej słowa wskazywałyby na to, że porzuciła go właśnie dlatego, że go kochała i bała się go stracić, a żadnej kolejnej straty po tym, co przeżyła wcześniej, już by nie zniosła (Murakami 586). Wydawało się jej, że lepiej odejść samemu, zanim się straci coś ważnego, niż stracić to naprawdę - jest to oczywiście ucieczka od życia, miłości i odpowiedzialności.

Kafka także jest zagrożony tym, że zagubi się w meandrach swojej nieświadomości, że ucieknie od rzeczywistych wyzwań rzeczywistości i od odpowiedzialności za swoje życie. Symbolizują to jego wycieczki w głąb lasu, do osady odizolowanej od świata, w której mógł już zostać na zawsze. Tam następuje zetknięcie z przestrzenią, gdzie nicość i treść dokładnie na siebie nałożyły, a przeszłość i przyszłość tworzą nieprzerwaną, nieograniczoną pętlę. „Błądzą tam znaki, których nikt nie czytał, akordy, których nikt nie słyszał" (Murakami 555). Jednak Kafka, poszerzając granice swojej świadomości kosztem nieświadomości, jest w stanie nie dopuścić do zalania swojej świadomości przez treści nieświadomości.

Uzyskanie dostępu do nieświadomości w sposób kontrolowany przez silne ego jest warunkiem zdrowia psychicznego. Siła, której pragnął Kafka, to nie siła umożliwiająca ucieczkę od rzeczywistości. To siła, która pozwala przeciwstawić się niesprawiedliwości, przeciwnościom losu, psychicznym załamaniom, siła umożliwiająca porozumienie i nawiązanie pozytywnych relacji międzyludzkich (Murakami 424). Bez silnego ego „otwarcie nieświadomości” jest groźne. Saeki umiera, gdyż straciła wolę do dalszego życia, pozwalając wyparte treści w nieświadomości nią zawładnęły.

\section{Pułkownik Sanders - archetyp Trickstera}

Inną groteskową i zagadkową postać w powieści Murakamiego, Pułkownika Sandersa, można uznać za archetypowy obraz Trickstera/Szachraja. Pułkownik Sanders, którego wizerunek znają wszyscy Japończycy, gdyż zdobi liczne restau- 
racje Kentucky Fried Chicken w tym kraju, wypowiada następujące słowa: „Jeśli nawet ukazałem się teraz tobie pod tymczasową postacią, to jednak nie jestem ani bóstwem, ani Buddą; natura uczyniła mnie obojętnym moralnie, toteż kieruję się innymi ocenami niż ludzie" (Murakami 380).

Słowa te są ukrytym cytatem z kolejnego opowiadania Uedy Akinariego ze zbioru Ugetsu monogatari pt. Hinpukuron (Dysputa o biedzie i fortunie), a wypowiada je Duch Złota, który nawiedził pewnego samuraja pod postacią „staruszka o niepozornej powierzchowności" (Ueda 230).

Użycie tego cytatu może świadczyć o tym, że Murakami uważa Ducha Złota za archetypowy obraz Trickstera. Opowiadanie Uedy Akinariego jest pochwałą gromadzenia majątku przez samurajów wbrew powszechnej opinii, że szlachectwo oznacza pogardę dla pieniędzy, jednak można doszukać się w postaci Ducha Złota cech wspólnych dla archetypu Trickstera. Przede wszystkim jest to moralna ambiwalencja. Duch złota nie kieruje się moralnością, nie uznaje autorytetu religii czy istnienia sił nadnaturalnych kierujących losem człowieka - ani buddyjskiego prawa odpłaty karmicznej za czyny popełnione w poprzednich wcieleniach, ani konfucjańskiej idei Woli Niebios. Człowiek sam kształtuje swój los, zyskuje gdy poznaje immanentne prawa natury, jak rolnik, który wie dzięki obserwacji, gdzie i kiedy należy zasiać odpowiednie uprawy oraz wie, jak je pielęgnować. Podobnie Pułkownik Sanders twierdzi, że nie stoi ponad dobrem i złem, jest po prostu pragmatyczny (Murakami 380).

Według Junga Trickster przywraca równowagę miedzy świadomością a nieświadomością (Casement 127) i to samo czyni Pułkownik Sanders, gdyż pomaga Nakacie odnaleźć „kamień otwierający wejście” i zamknąć je, a więc nie pozwolić, by nieświadome treści zalały świadomość. Należy powstrzymać zwłaszcza Cień, który jako czyste zło może siać spustoszenie, gdy opanuje świadome ego. Murakami zachował także błazeński charakter Trickstera w wypowiedziach Pułkownika Sandersa:

Na razie przybrałem łatwo rozpoznawalną, można powiedzieć kultową dla społeczeństwa kapitalistycznego, postać pułkownika Sandersa. Mogłem zostać Myszką Miki, ale Disney strasznie dba o prawa do swoich wizerunków. Nie chciałem, żeby podali mnie do sądu. (Murakami 379)

Nieprzypadkowo archetypy w powieści Murakamiego przybierają formę ikon popkultury. Jung zwracał bowiem uwagę na znamienny dla naszej epoki fakt, że archetyp, aby uniknąć gorszącej dziś personifikacji mitycznej, przyjmuje różne zaskakujące formy (Jung 256) ${ }^{12}$.

12 Jung analizował na przykład zjawisko niezidentyfikowanych obiektów latających jako obrazów archetypowych. 
Dzięki pomocy Pułkownika Sandersa Nakata najpierw używa „kamienia otwierającego wejście", a potem to wejście zamyka, a wszystko po to, by "przywrócić różnym rzeczom ich właściwy kształt" (Murakami 520). Należy zwrócić uwagę na to, że „kamień otwierający wejście” jest w powieści Murakamiego kamieniem, uważanym za substrat bóstwa, który ukryty jest w sanktuarium świątyni sintoistycznej. Nie wolno otwierać sanktuarium, gdyż jest to uważane za świętokradztwo, którego skutkiem jest kara ze strony bogów. Ma to symbolizować, że nie można naruszać granic, chroniących świadomość przed niekontrolowanym zalewem treści nieświadomości. Każdy, kto zamierza wkroczyć do świata nieświadomości indywidualnej czy zbiorowej, musi pamiętać ostrzeżenie zawarte w powieści Murakamiego: „Do pewnego miejsca możesz do niego wejść. I możesz bezpiecznie wrócić. Jeżeli będziesz uważny. Ale jak miniesz pewien punkt, już stamtąd nie wyjdziesz. Nie znajdziesz drogi powrotnej" (Murakami 470).

Podsumowując można powiedzieć, że ikiryō, czyli duchy żyjących osób w powieści Murakamiego pt. Kafka nad morzem są przede wszystkim metaforą treści nieświadomości indywidualnej, czyli tego, co zostało wyparte, zapomniane, odsunięte. Bez integracji tych treści nie jest możliwe funkcjonowanie silnej i odpowiedzialnej osobowości. Ikiryō są także związane z archetypem Cienia jako złem absolutnym, które nie jest abstrakcyjnym pojęciem, ale energią psychiczną związaną ze sferą emocji. Energia ta nie jest pod kontrolą podmiotowej świadomości, ale posiada pewną autonomię. „Archetypy wywołują ślepy na realia afekt, który bierze we władanie wolę" (Samuels, Shorter, Plaut 43). Symbolizuje to scena, w której z ciała zmarłego Nakaty, który stracił połowę Cienia i dlatego nie mógł nad nim panować, wydobywa się coś potwornego, co po długiej walce udaje się unicestwić Hoshino (Murakami 603). Można dojść do wniosku, że brak woli człowieka, by przeciwstawić się złu, które jest w nim samym, zostało najpełniej przejawione w archetypowym obrazie Cienia jako ikiryō, czyli duch osoby żyjącej, nad którym jej ego nie ma żadnej kontroli.

\section{BIBLIOGRAFIA}

Casement, Ann. Carl Gustav Jung. Przekład: Jacek Łaszcz. Gdańsk: Gdańskie Wydawnictwo Psychologiczne, 2007.

Enchi, Fumiko. Namiko monogatari (Opowieść o Namiko). Tōkyō: Shinchōsha, 1979.

Jacobi, Jolande. Psychologia C.G. Junga. Przekład: Stanisław Łypacewicz. Warszawa: Wydawnictwo Szafa, 2001.

Jung, Carl Gustav. Archetypy i symbole. Warszawa: Czytelnik, 1976.

Mishima, Yukio. Pani Aoi. Przekład: Henryk Lipszyc. Moi Bitlesi. Wybór dramatów japońskich. Warszawa: Dialog, 1998. S. 171-190.

Murakami, Haruki. Kafka nad morzem. Przekład: Anna Zielińska-Elliot. Warszawa: Warszawskie Wydawnictwo Literackie MUZA SA, 2007. 
Murasaki, Shikibu. Genji monogatari (Opowieść o księciu Genji). Nihon koten bungaku zenshū (Zbiór klasycznej literatury Japonii) t. 2. Tōkyō: Kōgakukan, 1972. S. 4-167.

Nihongi. Chronicles of Japan from the Eearliest Times to A.D.697. Red. W. G. Aston. Rutland, Vermont, Tokyō: Charles E. Tuttle Company, 1972.

Rodowicz, Jadwiga. Pięć wcieleń kobiety w teatrze nō. Warszawa: Wydawnictwo Pusty Obłok, 1993.

Samuels, Andrew, Shorter, Bani, Plaut, Fred. Krytyczny słownik analizy jungowskiej. Wrocław: Oficyna Wydawicza UNUS,1994.

Ueda, Akinari. Po deszczu przy księżycu. Przekład: Wiesław Kotański. Warszawa: Ossolineum, 1968. 